\title{
Corela
}

Cognition, représentation, langage

HS-29 | 2019

Questions et exclamations au prisme de plusieurs approches linguistiques

\section{Corpus : Exclamations Texte T. Williams}

\section{(2) OpenEdition}

Journals

Édition électronique

URL : http://journals.openedition.org/corela/8940

DOI : $10.4000 /$ corela. 8940

ISSN : 1638-573X

Éditeur

Cercle linguistique du Centre et de I'Ouest - CerLICO

Référence électronique

"Corpus : Exclamations Texte T. Williams », Corela [En ligne], HS-29 | 2019, mis en ligne le 09

septembre 2019, consulté le 28 octobre 2019. URL : http://journals.openedition.org/corela/8940

DOI : 10.4000/corela.8940

Ce document a été généré automatiquement le 28 octobre 2019

\section{(c) (1) (2) (2)}

Corela - cognition, représentation, langage est mis à disposition selon les termes de la licence

Creative Commons Attribution - Pas d'Utilisation Commerciale - Partage dans les Mêmes Conditions

4.0 International. 


\section{Corpus : Exclamations Texte $\mathrm{T}$. Williams}

Image

BLANCHE [faintly to herself]:

I've got to kecp hold of myself! [Stella comes quickly around the corner of the buildin

and runs to the door of the downstairs flat |

5 STELLA [calling out joyfully]:

Blanche! [For a moment they stare at each other. Then Blanche springs up and runs to her with a wild cry.

BLANCHE:

10 Stella, oh. Stella, Stella! Stella for Star! [She begins to speak with feverish vivacity as if she feared for either of them to stop and think. They catch each other in a spasmodic embrace. BLANCHE:

Now, then, let me look at you. But don't you look at me, Stella, no, no, no, not till later. not till $T$ ve bathed and rested. And turn that over-light off! Turn that off! I won' 7 be looked in this merciless glare! [Stella laughs and complies.]
Come back here now! Oh, my baby! Stella! Stella for Star! [She embraces her again.]

I thought you would never come back to this horrible place! What am I saying? I didn't mean to say that. I meant to be nice about it and say- $\mathrm{Oh}$, what a convenient location and

20 such-Haa-ha! Precious lamb? You haven't said a word to me.

STELLA:

You haven't given me a chance to, honey! [She laughs, but her glance at Blanche is a little

anxious. 1

BLANCHE:

Well, now you talk. Open your pretty mouth and talk while Ilook around for some liquor:

I know you must have some liquor on the place! Where could it be, I wonder? Oh. I spy. I

spy! [She rushes to the closet and removes the bottle, she is shaking all over and panting for

30 breath as she tries to laugh. The bottle nearly slips from her grasp.

STELLA [noticing:

Blanche, you sit down and let me pour the drinks. I don't know what we've got to mix

35 with. Maybe a coke's sin the icebox. Look' ns see, honey, while I'm-

BLANCHE:

No coke, honey, not with my nerves tonight! Where-where-where is -

STELLA:

40 Stanley? Bowling! He loves it. They're having a-found some sodal-toumament...

BLANCHE:

Just water, baby, to chase it! Now don't get worried, your sister hasn't turned into a

drunkard, she's just all shaken up and hot and tired and dirty! You sit down, now, and explain

5 this place to me! What are you doing in a place like this?

TELLA:

50 BLANCHE:

Oh, $\Gamma \mathrm{m}$ not going to be hypocritical, $\mathrm{\Gamma m}$ going to be honestly critical about it! Never, never, never in my worst dreams could I picture-Only Poe! Only Mr. Fdgar Allan Poe!could do it justice! Out there I suppose is the ghoul-haunted woodland of Weir! [She laughs.] 
Image

55 STELLA: No, honey, those are the $\mathrm{L} \& \mathrm{~N}$ tracks. BLANCHE:

No, now seriously, putting joking aside. Why didn't you tell me, why didn't you write me,

honey, why didn't you let me know?

STELLA [carefully, pouring herself a drink]:

BLANCHE:

Why, that you had to live in these conditions!

STELLA:

STELLA:
Aren't you being a little intense about it? It's not that bad at all! New Orleans isn't like

other cities.

BLANCHE: baby! [She suddenly stops short]

75 The subject is closed!

Thanks. [During the pause, Blanche stares at her, She smiles at Blanche.]
The [a litle driy]

80 BLANCHE [looking down at her glass, which shakes in her hand]:
You' re all T've got in the world, and you' re not glad to see me! STELLA [sincerely]:

Why, Blanche, you know that's not true.

5 BLANCHE:

No?-I'd forgotten how quiet you were

STELLA:

90 You never did give me a chance to say much, Blanche. So I just got in the habit of being quiet around you.

BLANCHE [vaguely]

A good habit to get into... [then, abruptly] You haven't asked me how I happened to get away from the school before the spring term ended.

Well, I thought you'd volunteer that information-if you wanted to tell me.

100 BLANCHE:

You thought T'd been fired?

No, - - thought you might have-resigned.

BLANCHE:

I was so exhausted by all Id been through my-nerves broke. [Nervously tamping

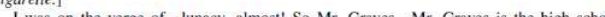

110 superintendent-he suggested I take a leave of absence. I couldn't put all of those details into

Oh, this buzzes right through me and feels so good!

Image

115 STELLA

BLANCHE:

No, one's my limit.

120 STELLA:

BLANCHE:

You haven't said a word about my appearance.

STELLA:

You look just finc

BLANCHE: God love you for a liar! Daylight never exposed so total a ruin! But you-you' ve put on
some weight, yes, you' $r$ just as plump as a little partridge! And it's so becoming to you!

STELLA:

135 Now, Blanc

BLANCHE:

UP.

Not now.

You hear me? I said stand up?
[Stella complies reluctantly?

You messy child, you, you've hair - you ought to have it cut in a feather bob with your dainty features. Stella, you have

maid, don't you?

150 STELLA:

N with sooms it's-

BLANCHE:

155 What? Two

STELLA:

This one and $—$ She is embarrassed.]

BLANCHE

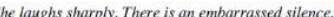

I am going to take just one little tiny nip more, sort of to put the stopper on, so to speak. Then put the bottle away so I won't t be tempted. [She rises.]

165 I want you to look at my figure! [She turns around.] You know I haven't put on one ounce in ten years, Stella? I weigh what I weighed the

STELLA [a little wearity

Il's just incredible. Blanche, how well you' re lookin

BLANCHE: [They both laugh uncomfortably]

the you're going to put me 
Image

10363A88000079B600008A65588297ED672DFFF2.emf

175 STELLA:

We're going to put you in here.

BLANCHE:

180 What ki

STELLA:
Does it feel all right?

Does it feel all right?

BLANCHE [dubiously]:
Wonderful, honey. I don't like a bed that gives much. But there's no door between the two rooms, and Stanley - will it be decent?

STELLA:

Stanley is Polish, you know.

BLANCHE:

Oh, yes. They' re something like Irish, aren't they?

95 STELLA:

BLANCHE:

Only not so-highbrow? [They both laugh again in the same way.]

Only not so-highbrow? [They both laugh again in the same way.
I brought some nice clothes to meet all your lovely friends in.

STELLA:

'm afraid you won't think they are lovely.

BLANCHE:

205 What are they like?

STELLA:

They're Stanley's friends.

210 BLANCHE:

Polacks?

STELLA:

215 They're a mixed lot, Blanche.

BLANCHE:

Heterogeneous-types?

STELLA:

220 Oh, yes. Yes, types is right!

BLANCHE:

Well-anyhow - I brought nice clothes and I'll wear them. I guess you're hoping I'll say

225 with somebody. I can't be alone! Because - as you must have noticed-I'm-not very well.... [Her voice drops and her look is frightened.] 